\title{
Metal Alloys, Metal Deposits and Workshop Centres
}

In a discussion about metal and metallurgy in Ancient Nubia, we cannot ignore Egypt and the influence of Mesopotamian metallurgy in Egypt. Knowledge of Nile Valley metalworking came from the study of smelting scenes from Egyptian tombs. Such a study can assess the techniques, the tools used by bronze-workers, and their evolution. However, this approach has limitations. In the Old and New Kingdoms, paintings and reliefs depicting copper are numerous and allow analysis and comparisons, while Middle Kingdom representations are very basic and only include the melting scenes. Nevertheless, many of the techniques used, especially melting and hammering, could be similar to those associated with copper working, while devices employed like furnaces, crucibles and ventilation methods could be likewise. Iconography, archaeological remains, and artefacts allow us to understand the selection and the exploitation of ores, the reconstitution of the various steps necessary for the manufacture of weapons, and the techniques and instruments required for this production (Drici 2016, 12-13).

Metal artefacts were found at the Neolithic site of Badari in Middle Egypt. Metal processing became common during Nagada I-III. The first items of metalwork were imported from Mesopotamia to Egypt. The Egyptians worked mines in Egypt and Sudan and were responsible for the spread of metalworking across Ancient Nubia (Scheel 1989, 8-10). Nubians and Egyptians made use of the same raw material deposits.

\section{$1 \quad$ Gold}

Large parts of the Eastern Desert (in the region around Aswan) belong to the Precambrian basement of the Arabian-Nubian shield, where around 250 sites of gold production have been recorded. Gold artefacts of prehistoric date $(c .3500$ BC) have been discovered in Egypt. During the Old Kingdom, the Egyptians worked gold mines in Wadi Hammamat, Wadi Abbed, and Wadi Sid in the Eastern Desert. Mines in the area of Gebel Komotit and Gebel el-Nigeim, also in the Eastern Desert, supplied gold to Kerima during the Kerma period. By the Middle Kingdom, deposits in Lower Nubia, Wadi Allaqi and Wadi el Hudi, and deposits between Buhen and Semna, were being mined by the Egyptians. In the New Kingdom, gold production sites further to the south of Nubia, like Sai
Island, Shamkhiya, Tanta, and Mograt Island were being worked. Ptolemaic gold mining was concentrated mainly in the central Eastern Desert in the area of Qena-Safaga, Quft-Qoseir, and the Edfu-Berenike Road. During Roman and Byzantine times, gold production decreased. Attacks by the Blemmyes forced the Romans to keep to wellprotected fortifications and protected roads in the Eastern Desert (Klemm, Klemm, and Murr 2001, 643, 654-656; Scheel 1989, 11; Castiglioni, Castiglioni, and Bonnet 2010, 267).

\section{$2 \quad$ Copper}

Copper was used in Ancient Egypt too. Egyptian copper was hard because of its natural content of arsenic. Copper ores were mined in the Eastern Desert in Beni Suef, Wadi Araba, north-west of Berenike, in Sinai, and in the Red Sea Hills. The Old Kingdom settlement of Buhen, in what is now Sudan, was a centre of copper production. Deposits in Wadi Araba were probably mined during the New Kingdom (Scheel 1989, 14; El Gayar and Jones 1989, 32, 38).

\section{$3 \quad$ Electrum}

Electrum, an alloy of gold and silver, was known in Egypt by the Predynastic period, and was mainly imported to Egypt from Nubia and from the Land of Punt (Scheel 1989, 15-16).

\section{$4 \quad$ Silver}

The Egyptians had used silver since Predynastic times, importing it from Mesopotamia, Crete and Cyprus (Scheel $1989,16-17)$.

\section{$5 \quad$ Iron}

The earliest iron objects found in Egypt were made from meteoric iron, but there is no evidence of iron production in early Ancient Egypt. In the New Kingdom, Egyptians imported iron from the Peloponnese, the Near East and Cyprus. Magnetite deposits in the Eastern Desert between 
Aswan and Ahellal, and in the Nile Delta at Naucratis, were mined around the 6th century BC. Workshops and deposits excavated at Meroe and Hamdab and dated to the 3 rd to mid-6th century AD played a significant role in iron production for Ancient Nubia in Meroitic and postMeroitic times (Scheel 1989, 17; Humphris and Scheibner 2017, 378, 396). One post-Meroitic ironworking centre, located in Hosh el-Kafir (close to El-Hobagi) and dated to AD 340-564, had a simple smithing workshop, but the iron had been imported to the site (Abdelrahman 2011, 394). 